\title{
Academic Leadership Courses: Catalysts for Students' Retention and Graduation
}

\author{
Krista M. Soria, PhD \\ Analyst \\ Office of Institutional Research \\ University of Minnesota \\ Linnette Werner, PhD \\ Interim Assistant Vice Provost for Student Life \\ Director of the Leadership Minor \\ University of Minnesota
}

\begin{abstract}
The purpose of this paper is to examine whether students' completion of an introductory leadership minor course is associated with their first-year retention and their four-year graduation or continued enrollment. The authors used propensity score matching techniques and discovered that first-year students who enrolled in an academic leadership course had significantly greater odds of retention, graduation in four years (over withdrawal), and continued enrollment in four years (over withdrawal) compared to their peers who did not enroll in an introductory leadership minor course.
\end{abstract}

\section{Introduction}

Over the last decade, researchers have investigated the outcomes of formal leadership development programs for college students; for instance, Zimmerman-Oster and Burkhardt (1999) discovered that undergraduates who participated in leadership training had increased civic responsibility, leadership skills, multicultural awareness, and community orientation. Dugan and Komives (2010) found that undergraduates who participated in both short-term and moderateterm leadership training programs reported significant increases in a number of areas indicative of socially responsible leadership. Specifically, students who participated in short-term leadership programs were more likely to possess abilities to collaborate with others in the pursuit of social change. Leadership trainings of moderate duration were positively associated with students' ability to work with others across difference, work well with others to pursue common outcomes, and believe that they can make a difference in their communities. Similarly, Soria, Nobbe, and Fink (2013) found that students who participated in college leadership experiencesincluding trainings or leadership positions-were significantly more likely to report higher scores on all seven scales of socially responsible leadership.

Similar effects have also been observed among students enrolled in academic leadership courses; for instance, in partnership with the Higher Education Research Institute, ZimmermanOster and Burkhardt (1999) discovered that undergraduates enrolled in academic leadership courses reported, on average, significantly greater theoretical knowledge about leadership and a 
stronger interest and willingness to develop leadership capacities in others. Researchers at Florida State University have also investigated the effects of students' enrollment in a leadership certificate program on student outcomes, finding that students scored significantly higher on socially responsible leadership, understanding of leadership, and leadership capacity (Guthrie \& Bovio, 2014).

While, undoubtedly, leadership development is a critical outcome of students' experiences in higher education (Cress, Astin, Zimmerman-Oster, \& Burkhardt, 2001; Eich, 2008; Thompson, 2006), college and university administrators are under increasing national public pressure to ensure that students who enroll in their programs are successful in meeting degree completion outcomes (DeAngelo, Franke, Hurtado, Pryor, \& Tran, 2011; White House Office of the Press Secretary, 2009). Under the auspices of mounting concerns over the quality of American higher education institutions and the nation's global competitiveness, policymakers have called upon higher education administrators to introduce new reforms to enhance students' degree completion rates - or to learn more about the types of promising practices that might already exist upon their campuses and to expand those opportunities to all students (Bresciani, 2006).

Yet, amid the increasing emphasis on students' degree completion outcomes, researchers in the field of leadership studies have rarely investigated whether academic leadership courses can positively impact students' retention or graduation. Predominant theories of retention suggest that students who are academically and social integrated in their college campuses, are involved in campus life, and are more engaged on campus are more likely to persist until graduation (Astin, 1984; Kuh, 1995; Tinto, 1993). While retention and student success research has burgeoned over the last several decades, higher education institutions across the nation remain beset by low retention and graduation rates; for instance, only $59 \%$ of first-time, full-time undergraduate students at four-year colleges graduate with a bachelor degree in six years. There are also significant disparities in the educational attainment outcomes by socioeconomic status and race/ethnicity: students from low-income, underrepresented, or underserved backgrounds are significantly less likely than their peers to successfully earn college degrees (Tinto, 2012). Therefore, studies into programs that can bolster students' retention and graduation rates remain valuable in the field of higher education.

The first purpose of this study is to analyze whether first-year college students who enroll in an innovative academic leadership course within a leadership minor program are significantly more likely than their peers to be retained from their first-year of enrollment to their second year of enrollment. The second purpose of this study is to analyze whether first-year students who enrolled in the leadership minor course were also more likely than their peers to graduate or remain enrolled within four years of enrollment. Among several studies that have explored students' retention as a consequence of participation in program such as academic leadership courses, a consistent shortcoming is that many fail to take into consideration the wide variety of factors that may lead students to enroll in leadership programs that may, in turn, be related to the retention outcomes of interest. To address those limitations, we utilized quasi-experimental procedures (propensity score matching techniques) to construct control groups (non-leadership course enrollees) and treatment groups (leadership course enrollees) similar to those found in 
randomized experiments. We utilized these innovative steps to reduce the potential bias found within students' self-selection into leadership courses.

\section{Leadership Minor}

The leadership minor program at the large, public research-extensive university featured in this study enrolls approximately 1,700 undergraduate students across four courses every academic year. The university enrolls over 29,000 undergraduate students each year within several large colleges, including liberal arts; science and engineering; biological sciences; business and management; education and human development;, and food, agriculture, and natural resource sciences colleges. The leadership minor program is situated within the college of education, the graduate school of public administration, and the central student affairs unit.

Instructors within this program employ an innovative pedagogy called Intentional Emergence (Werner et a., 2016; Werner, 2014; Werner \& Hellstrom, 2016), in which the context of the classroom environment itself becomes a laboratory within which students explore their leadership development. The context of the classroom is emergent, meaning that it is dynamic and continuously unfolding as the class progresses. Instructors are intentional about their desires for a specific class or for a course as a whole, although they may adapt the plan in the moment in order to respond to the emergent context of the developing class.

The authentic, intentional context that has just emerged brings with it tension, conflict, real-world consequences, empathy, and genuine interest. The leadership program is also grounded in Astin and Astin's (2000) social change model for scaffolding curriculum across four tiered courses and utilizes strengths-based approaches in each course. We examined the introductory course, which is open to all students at the University. The introductory leadership minor course is organized around five primary objectives in which students will 1) increase selfawareness as it relates to leadership capacities and begin to develop skills to enhance personal leadership; 2) gain an awareness of aspects of identity and how to lead across difference; 3) develop a personal definition of what it means to lead and of the role of personal responsibility in leadership; 4) develop and demonstrate critical thinking skills through written and presentation assignments; and, 5) identify aspects of their own leadership journey that demonstrates and integrates classroom learning, leadership experiences, and personal reflections. We outline the various components of those five themes below.

Self-Awareness of Leadership Capacities. Instructors in the leadership minor course ask students to engage in weekly tasks to explore the nuances of maintaining a delicate balance of moving between the balcony and dance floor (Heifetz \& Linsky, 2002); for instance, instructors ask students to develop their own class attendance policy and then ask students, throughout the process - which usually takes several weeks - to share what they are learning about the challenges of leading others through a difficult and often contentious task.

As a part of this course, instructors also ask students to explore and identify their personal values (Fritz \& Guthrie, 2017), their conflict styles (Wimmer, Meyers, Porter, \& Shaw, 2012), and write about moments in which they experienced ethical dilemmas so that they can begin to understand the challenges inherent to ethical dilemmas (Kidder, 2003). Additionally, students 
take the Clifton StrengthsFinder to discover their top five strengths, learn the top five strengths of classmates in their community, and develop project teams to ensure diverse representation from the four strengths-based leadership domains (Rath \& Conchie). Instructors ask students to reflect upon their strengths and how they can be utilized in their leadership experiences (Soria, Roberts, \& Reinhard, 2015).

One important value espoused in the introductory leadership minor class is that everyone in the class is already a leader. This relational view of leadership (Wagner, 2013), purposefully shared as a foundation for the introductory course, is important as a catalyst to help students become aware of their leadership so that they can engage in leadership opportunities, take on new leadership responsibilities in class (e.g., by volunteering to lead tasks), and continue to develop their leadership identity (Komives, Owen, Longerbeam, Mainella, \& Osteen, 2005).

Identity Awareness and Leading across Differences. Instructors ask students to complete a social identity profile (The Program on Intergroup Relations at the University of Michigan, 2007) in which they examine demographic aspects of their identities, such as gender, sex, race, ethnicity, sexual orientation, social class, age, dis(ability); elements of their identities that are more mutable, such as education, parents' education, geographic location, employment background, and experiences with mental illness; and affiliations with groups/organizations or more extended experiences (e.g., divorced parents). Students identify those elements and instructors ask them to discuss (in small groups) which identities are most or least salient to them, which identities mean the most to them, and how those identities influence how others perceive them.

The self-awareness components, coupled with small group discussions and reflections, inspire students to learn about the different life experiences of their classmates based upon their social identities. As an introduction to discovering differences, students have a one-to-one conversation with a classmate outside of class and write a reflection paper about the experience. Students are encouraged to approach the conversation from a "seek to understand" mindset, enter the conversation with questions designed to discover meaningful similarities or differences between them and their peers, and reflect upon the experience by providing examples of how they have changed as a consequence of understanding their peers. Continuing to build these interpersonal connections, students in many individual sections of the course develop online communities through Facebook or Groupme, an interactive group app to share course-related information, invite classmates to events, or send reminders about assignment due dates.

Instructors also assign students to read about White privilege from two different college students' perspectives (Fortgang, 2014; Jerkins, 2014), leadership from different cultural lenses (Bordas, 2007), and the social construction of difference (Johnson, 2001). Students work on culminating final projects in groups and, through reflection papers and videos, discuss team members' roles and contributions (Komives, Lucas, \& McMahon, 1998). These experiences, class readings, and facilitated discussions lead to an awakened development of multicultural appreciation and an understanding of power, privilege, and social systems.

Personal Definition of Leadership. In the beginning of the semester, students write down their definition of leadership and instructors retain a copy. At the end of the semester, 
students again write a definition of leadership, instructors hand back their original leadership definitions, and students reflect upon the differences (if any) between their first and second definitions (Haber, 2012). Students also read and learn about the elements of the social change model (Wagner, 2013), how their coursework connects to the social change model, and how the social change model can serve as a foundation for their engagement in social change in the future In a final reflection paper, students also write about their vision of their personal responsibility in leadership and create a vision for their future leadership (Archbald, 2013).

Critical Thinking Skills. According to the National Council for Excellence in Critical Thinking (Scriven \& Paul, 1996), critical thinking has two major components: 1) a set of information and belief generating and processing skills, and 2) the habit, based on intellectual commitment, of using those skills to guide behavior. It is thus to be contrasted with: 1) the mere acquisition and retention of information alone, because it involves a particular way in which information is sought and treated; 2) the mere possession of a set of skills, because it involves the continual use of them; and 3) the mere use of those skills ("as an exercise") without acceptance of their results. (para. 5)

In the spirit of this definition, students complete several course assignments to develop their critical thinking skills, including a team project in which they analyze several components of a provocative statement (e.g., the minimum wage should be increased to $\$ 15$ per hour), identify peer-reviewed resources for several sides of the provocative statement issue (e.g., for or against an increase in minimum wage), and discuss, as a team, whether their personal perspectives or opinions on the topic have changed as a consequence of continued research on the topic. In addition, students complete critical reading reflections in which they critically analyze the content, their own reactions to the material, and how the reading connects to other aspects of the course or their own lives with the intention that by the end of the semester they are more likely to critically evaluate future readings.

As Scriven and Paul (1996) suggested, critical thinking includes forming habits of mind instead of acquiring temporary information. For this reason, the curriculum in this course uses a spiraling approach. For example, the concept, "leaders seek to understand" is introduced at the same time that identity work happens and this is followed up with students interviewing each other about their own identities. These ideas come back again (spiral in) when students give formal presentations to the class about their leadership journeys and then spiral back again a few weeks later when the instructor introduces formal readings and activities related to power and privilege. Through this spiraling exposure to related concepts, students make long-term and more complex connections with the ideas. By revisiting the same ideas repeatedly, students critically analyze their own growth with the concepts as well as the concepts themselves.

Leadership Journey. As mentioned above, one-third of the way through the semester, students develop a presentation in which they outline the key moments of their leadership journeys so far. In the middle of the semester, students have a one-to-one conversation with an individual - someone who exemplifies living with passion and purpose. Instructors encourage students to take a risk and reach out to someone who they do not already personally know very well, with whom they have no connections, or with someone with whom they have a small connection (e.g., business owner who knows a students' mother). The intention behind the 
assignment is to help students reflect upon how passion and purpose shows up in their lives, to stretch outside of their comfort zones (Liepold, Rasmussen, Boyce, \& Trudeau Poskas, 2013), to develop skills to ask provocative questions that reveal interesting and revealing stories (HaberCurran \& Tillapaugh, 2013), and to develop social capital in the form of knowledge, guidance, inspiration, or mentorship as a result of the meeting. Students also write a leadership journey paper at the end of the semester, an assignment in which students identify aspects of their leadership journey, utilize course concepts, and integrate readings and experiences in classes to form a comprehensive reflection upon their growth as a leader.

\section{Conceptual Framework}

Like previous studies examining the effects of students' participation in specific programs on their retention outcomes, in this study, we used Astin's (1993) input-environmentoutput model as our conceptual framework. The "inputs" within this model include students' precollege characteristics, experiences, and demographics. The environment includes experiences during higher education and the outputs include first-year students' retention to their second year and their rate of graduation or continued enrollment in their fourth year of study. Inputs can have an effect on both environmental experiences and outcomes, which is why researchers commonly take inputs into consideration when building their statistical models. Indeed, to test the true impacts of environmental experiences (e.g., enrollment in leadership minor courses), it is important to consider the direct effects of input variables on outcomes while also examining the potential effects those input variables also have on the environmental variables. In the case of students' enrollment in the first-level leadership course in the leadership minor program, for instance, self-selection bias may contribute to systematic differences between students who enroll and those who do not enroll.

\section{Methodology}

Participants. The sample utilized in this study is drawn from the 2012 entering class of first-year undergraduates at a large, public, research-extensive university located in the Midwest $(n=5,514)$. The sample included slightly more females $(n=2,798,50.7 \%)$ than males $(n=$ $2,716,49.3 \%)$. Within the full sample, $5.2 \%$ were international students $(n=285), 2.8 \%$ Hispanic $(n=155), 1.1 \%$ American Indian or Native American $(n=60), 11.8 \%$ Asian $(n=650)$, $3.4 \%$ Black $(n=188), 0.4 \%$ Hawaiian $(n=24), 74.9 \%$ White $(n=4,132)$, and $0.3 \%(n=19)$ had a non-specified race/ethnicity.

Of the entire first-year class, 159 students (2.9\%) had taken the introductory leadership course in their first year of enrollment. We used this sub-sample for matching purposes. Within the sub-sample of students who enrolled in the leadership minor course, $53.5 \%(n=85)$ were female and $46.5 \%(n=74)$ were male, $2.5 \%$ were American Indian or Native American $(n=4)$, $12.6 \%$ Asian $(n=20), 3.8 \%$ Black $(n=6), 0.6 \%$ Hawaiian $(n=1), 3.8 \%$ Hispanic $(n=6), 6.9 \%$ international $(n=11)$, and $69.8 \%$ White $(n=111)$.

Our use of first-year students only in this study was intentional because we sought to take steps to eliminate potential confounding biases that may impact students' success so as to better isolate the effects of enrollment in an introductory leadership minor course. For example, if we 
had studied juniors' or seniors' enrollment in a leadership minor course, students' graduation could be attributed to their ongoing persistence instead of participation in the minor programthose students would only have one or two years to finish their degrees, so they may decide to stay and complete their education as opposed to transferring or withdrawing given that they have completed so many credits already. Furthermore, these students may have already engaged in any number of collegiate experiences associated with higher graduation rates, so narrowing our sample to first-year college students reduces the chance that confounding variables would interfere with our ability to more accurately judge the impact of enrollment in a leadership minor course.

\section{Measures.}

Covariate measures. The covariate measures utilized for propensity score matching analyses were intentionally selected because of their known relationships to enrollment in a leadership minor program. These variables include students' sex, college of enrollment, race/ethnicity, ACT/SAT scores, enrollment in a freshman seminar course, enrollment in an Honors program, first-generation status, campus residency, and socioeconomic status as measured by Pell grant receipt.

Environmental measures. The primary environmental measure of interest was enrollment in an introductory leadership course within the leadership minor program. This course is a three-credit course graded A-F and $49.05 \%(n=78)$ of the students took the course in the fall semester while $51.95 \%(n=81)$ took the course in the spring semester. Within the first-year class of students, an additional 208 students eventually went on to take an introductory leadership minor course in their later years' of enrollment and were subsequently excluded from matching analyses.

Outcomes measures: Students' retention, graduation, and continued enrollment. The dependent variables of interest in this study included first-year students' rate of retention to their second year of enrollment, graduation in four years, and their rate of continued enrollment in four years (if not yet graduated or withdrawn). In the entire sample of first-year students, $9.6 \%$ of the original class of 5,514 were not retained to their second year, $65.2 \%$ graduated, $18.0 \%$ withdrew, and $16.8 \%$ were still enrolled.

Data Analyses. We utilized propensity score matching techniques in SPSS 23.0 using the procedures outlined by Thoemmes (2012). We began by using binary logistic regression to compute propensity scores for individual students. Next, we used 1:1 nearest neighbor matching, meaning that each student in the treatment condition is matched to a student in the untreated condition who has the most similar estimated propensity score. We matched without replacement and we discarded all units that fell outside of the area of common support to avoid extrapolation to units that were so dissimilar that no comparisons could be made to other units (Thoemmes, 2012). Next, it was important to check whether the matching procedures balanced the distribution of variables in both the treatment and control groups. We examined the standardized mean differences (the mean differences between the two groups divided by the standard deviation of the control group) in the treatment and control groups before and after matching. We detected no large imbalances above .25 after matching in each analyses, meeting the threshold suggested by Rosenbaum and Rubin (1985). These results suggest that, before matching 
procedures were implemented, the covariates within the treatment and control groups differed significantly. These results also suggest that the propensity score matching decreased bias by making the observed and treatment groups more similar with regard to their covariates.

To test whether there are significant differences between leadership course enrollees' and non-enrollees' retention rate from year one to year two, we used binary logistic regression. Whereas beta coefficients, standard errors, and significance levels are commonly used to describe the results of ordinary least squares regression, odds ratios - which are calculated by exponentiation of the beta coefficient $\left(\mathrm{e}^{\beta}\right)$ - are used in logistic regression to explain how a change in an independent variable influences the dependent variable when other variables are held constant (Cragg, 2009; Hosmer \& Lemeshow, 2000). In the context of the present study, the odds ratio value indicates the odds of re-enrollment in the second year of higher education for every one-unit increase in an independent variable when other variables are held constant.

Additionally, to measure differences in graduation rates in four years or continued enrollment in four years, we used multinomial logistic regression analyses. Multinomial logistic regression techniques are appropriate when comparing several outcomes against a referent variable. In this instance, we compared the odds of graduating in four years and the odds of continued enrollment after four years against withdrawal from the university.

\section{Limitations}

There are several limitations in the current study that could limit generalizability to other undergraduate students; for instance, the sample is drawn from a large, public research university. While those types of institutions enroll a substantial percentage of undergraduates across the U.S. each year, the resources and opportunities available at those universities can differ drastically from those at community colleges, liberal arts colleges, or regional institutions. The students primarily took the leadership courses face-to-face, although there were a handful of students who enrolled in the online section of the leadership courses. Programs that offer alternative course formats (e.g., predominantly online courses, short 1-credit courses) may not see similar results in their own programs. Furthermore, our sample included mostly "traditional" students with regards to age (18-19 year old students) and was primarily White students, suggesting limited generalizability to other leadership programs that enroll students from more diverse backgrounds.

\section{Results}

The binary logistic regression predicted first-year students' retention from their first year of enrollment to their second year of enrollment. The results suggest that first-year students who enrolled in a leadership minor class had significantly greater odds of continued enrollment to their second year of study $\left(\mathrm{e}^{\beta}=6.692, p<.001\right)$ over their peers who did not enroll in a

leadership minor introductory course. Specifically, an examination of the odds-ratio suggests that first-year students who enrolled in the leadership minor course were over six times more likely to re-enroll for their second year controlling for their propensity to enroll in the course. The pseudo$R^{2}$ values were .044 using Cox and Snell's measurement (1989) and .114 using Nagelkerke's (1991) measurement. The models properly classified between $93.4 \%$ of the cases and the 
Hosmer-Lemeshow (1989) goodness-of-fit test statistic was not significant, implying that the models' estimates fit the data at an acceptable level.

The multinomial logistic regression predicted the odds of students remaining enrolled in four years over withdrawing and the odds of graduating in four years over withdrawing. The results suggest that first-year students who enrolled in a leadership minor class had significantly greater odds of continued enrollment after four years over withdrawal $\left(\mathrm{e}^{\beta}=2.592, p<.001\right)$ and greater odds of graduating in four years (over withdrawal) $\left(\mathrm{e}^{\beta}=2.432, p<.001\right)$ compared to their peers who did not enroll in a leadership minor introductory course. The pseudo- $R^{2}$ values were .017 using Cox and Snell's measurement (1989) and .021 using Nagelkerke's (1991) measurement. The Pearson and deviance tests were not significant, suggesting the model is a good fit to the data and the chi-square test, which tests the decrease in unexplained variance from the baseline data, were significant, which means the final model explained a significant amount of variability than the original model.

\section{Discussion}

The results of the initial analyses of the impact of enrollment in a leadership minor introductory course suggest that the course had positive effects on students' retention and graduation or continued withdrawal after four years of enrollment. It is important to note that the overall effects of the leadership minor are very small, suggesting there are several other variables not included in the analyses that may be more strongly associated with students' retention and graduation; for instance, several decades ago, Pascarella and Terenzini (1979) cited contact with peers and faculty as the single leading factors associated with students' retention, findings corroborated by other researchers who have discovered positive associations between college students' social support and their retention (Foley Nicpon, et al., 2006; Mattanah, Ayers, Brand, \& Brooks, 2010; Mattanah, Brooks, Brand, Quimby, \& Ayers, 2012). Additional factors, such as academic self-efficacy, are also strong and positive predictors of students' retention and academic success (Chemers, $\mathrm{Hu}, \&$ Garcia, 2001); however, these additional variables were not included in our analyses.

There may be several components of the leadership minor introductory course experience that lead to enhanced student outcomes; for instance, the leadership minor classes are relatively small $(<30)$ compared to other introductory courses at this large, public research university (which sometimes enroll up to 1,000 students). The smaller, more intimate class experience may enhance students' abilities to network with their peers and increase their sense of belonging, thus leading to greater retention (Herzog, 2007; Pascarella \& Terenzini, 2005; Strayhorn, 2012). Additionally, intentional opportunities for students to be authentic, courageous, and vulnerable throughout the entire class may have fostered the development of friendships and unique connections with classmates and instructors (Crappell, 2013; Huddy, 2015), thus also helping to connect students to the campus and increasing their desire to persist and graduate (Sutton, 2016).

Furthermore, the inclusion of strengths-related programming as a means of developing students' self-awareness may lead not only to their leadership development (Soria, Roberts, \& Reinhard, 2015) but also their enhanced sense of belonging (Soria \& Stubblefield, 2015a), academic self-confidence (Soria \& Stubblefield, 2014), engagement (Soria \& Stubblefield, 2014; 
Soria \& Taylor, Jr., 2016), and retention (Soria \& Stubblefield, 2015b). Opportunities for students to meet one-on-one with their faculty and classmates (Eckles \& Stradley, 2012), develop interactive online communities (Astin, 1993; Gray, Vitak, Easton, \& Ellison, 2013), as well as group projects and experiential learning activities (Prussia \& Weis, 2004), may have also facilitated students' success.

Finally, it is possible that the intentional emergence framework for teaching the courses may wean students off of dependence upon formal authority (i.e., unlearning traditional educational authority systems) so that they begin to take charge of their learning and become increasingly responsible for achieving their educational goals (Werner et al., 2016). Students may feel a sense of heightened self-authorship within the learning partnerships that are constructed in the leadership courses (Pizzolato \& Ozaki, 2007): closely paralleling the learning partnership model (Baxter Magolda, 2004), in the introductory leadership minor course, students are validated as leaders, the learning is situated in their leadership experiences, and leadership is understood as mutually constructed and dynamic. By providing spaces within which students are encouraged to "make meaning without formulas" (Pizzolato \& Ozaki, 2007, p. 198), instructors help students to relinquish a belief in absolute definitions of leadership (the crossroads), look internally and develop a self-awareness of themselves as leaders (becoming the author of one's own life), and construct new awareness of leadership as building relationships with others (internal foundations) — the three-phase journey toward self-authorship (Baxter Magolda, 2001).

\section{Conclusion}

The results of this study suggest that first-year students who enrolled in an introductory leadership minor course had significantly greater odds of retention, graduation in four years (over withdrawal), and continued enrollment in four years (over withdrawal) compared to their peers who did not enroll in an introductory leadership minor course. While the results from this study are interesting, we acknowledge that several of the limitations of this study impede not only our full understanding of the impacts of academic leadership courses on students' outcomes given the constellation of variables that can also help to explain students' success, but also the generalizability of these results to other institutions. Therefore, we encourage researchers to continue examining the effects of academic leadership courses on students' educational success. 


\section{References}

Archbald, D. (2013). Vision and leadership: Problem-based learning as a teaching tool. Journal of Leadership Education, 12(2), 136-147.

Astin, A. W. (1984). Student involvement: A developmental theory of higher education. Journal of College Student Personnel, 25, 297-308.

Astin, A. W. (1993). What matters in college: Four critical years revisited. San Francisco, CA: Jossey-Bass.

Astin, A. W., \& Astin, H. S. (2000). Leadership reconsidered: Engaging higher education in social change. Battle Creek, MI: W. K. Kellogg Foundation.

Baxter Magolda, M. B. (2001). Making their own way: Narratives for transforming higher education to promote self-authorship. Sterling, VA: Stylus.

Baxter Magolda, M. B. (2004). Learning partnerships model: A framework for promoting selfauthorship. In M. B. Baxter Magolda \& P. M. King (Eds.), Learning partnerships: Theory and models of practice to educate for self-authorship (pp. 37-62). Sterling, VA: Stylus.

Bordas, J. (2007, September 11). How salsa, soul, and spirit strengthen leadership. Executive Forum, 46, 35-41.

Bresciani, M. (2006). Outcomes-based academic and co-curricular program review: A compilation of institutional good practices. Sterling, VA: Stylus.

Chemers, M. M., Hu, L-T., \& Garcia, B. F. (2001). Academic self-efficacy and first year college student performance and adjustment. Journal of Educational Psychology, 93(1), 55-64.

Cox, D. R., \& Snell, D. J. (1989). The analysis of binary data (2 $2^{\text {nd }}$ Ed.). London, UK: Chapman \& Hall.

Cragg, K. M. (2009). Influencing the probability for graduation at four-year institutions: A multimodal analysis. Research in Higher Education, 50, 394-413.

Crappell, C. (2013). Dealing with narcissism are our students self-absorbed or just afraid? American Music Teacher, 62(6) 10-12.

Cress, C. M., Astin, H. S., Zimmerman-Oster, K., \& Burkhardt, J. C. (2001). Developmental outcomes of college students' involvement in leadership activities. Journal of College Student Development, 42, 15-27. 
DeAngelo, L., Franke, R., Hurtado, S., Pryor, J. H., \& Tran, S. (2011). Completing college: Assessing graduation rates at four-year institutions. Los Angeles, CA: Higher Education Research Institute, University of California Los Angeles.

Dugan, J. P., \& Komives, S. R. (2010). Influences on college students' capacities for socially responsible leadership. Journal of College Student Development, 51(5), 525-549.

Eckles, J. E., \& Stradley, E. G. (2012). A social network analysis of student retention using archival data. Social Psychology of Education, 15(2), 165-180.

Eich, D. (2008). A grounded theory of high-quality leadership programs. Journal of Leadership \& Organizational Studies, 15(2), 176-187.

Foley Nicpon, M., Huser, L., Hull Blanks, E., Sollenberger, S., Befort, C., \& Robinson Kurpius, S. E. (2006). The relationship of loneliness and social support with college freshmen's academic performance and persistence. Journal of College Student Retention: Research, Theory, and Practice, 8(3), 345-358.

Fortgang, T. (2014, April 2). Checking my privilege: Character as the basis of privilege. The Princeton Tory. Retrieved from http://theprincetontory.com/main/checking-my-privilegecharacter-as-the-basis-of-privilege/

Fritz, M. R., \& Guthrie, K. L. (2017). Values clarification: Essential for leadership learning. Journal of Leadership Education, 16(1), 47-63.

Gray, R., Vitak, J., Easton, E. W., \& Ellison, N. B. (2013). Examining social adjustment to college in the age of social medial: Factors influencing successful transitions and persistence. Computers \& Education, 67, 193-207.

Guthrie, K. L., \& Bovio, B. (2014). Undergraduate certificate in leadership studies: An opportunity for seamless learning. Journal of College and Character, 15(1), 25-31.

Haber, P. (2012). Perceptions of leadership: An examination of college students' understandings of the concept of leadership. Journal of Leadership Education, 11(2), 26-51.

Haber-Curran, P., \& Tillapaugh, D. (2013). Leadership learning through student-centered and inquiry-focused approaches to teaching adaptive leadership. Journal of Leadership Education, 12(1), 92-116.

Heifetz, R. A., \& Linsky, M. (2002). Leadership on the line: Staying alive through the dangers of leading. Boston, MA: Harvard Business School Press.

Herzog, S. (2007). The ecology of learning: The impact of classroom features and utilization on student academic success. New Directions for Institutional Research, 135, 81-106. 
Hosmer, D. W., \& Lemeshow, S. (2000). Applied logistic regression ( $2^{\text {nd }}$ ed.). New York, NY: Wiley-Inter-Science Publication.

Huddy, S. (2015). Vulnerability in the classroom: Instructors' ability to build trust impacts the student's learning experience. International Journal of Education Research, 10(2), 96103.

Jerkins, M. (2014, May 6). The other side of privilege at Princeton. Ebony Magazine. Retrieved from http://www.ebony.com/news-views/the-other-side-of-privilege-at-princeton029\#axzz4gc3VJ5MW

Johnson, A. G. (2001). Privilege, power, and difference. Boston, MA: McGraw-Hill.

Kidder, R. M. (2003). Overview: The ethics of right vs. right. How good people make tough choices. New York, NY: Simon \& Schuster.

Komives, S. R., Lucas, N., \& McMahon, T. R. (1998). Interacting in teams and groups. Exploring leadership: For college students who want to make a difference. San Francisco, CA: Jossey-Bass.

Komives, S. R., Owen, J. E., Longerbeam, S. D., Mainella, F. C., \& Osteen, L. (2005). Developing a leadership identity: A grounded theory. Journal of College Student Development, 46(6), 593-611.

Kuh, G. D. (1995). The other curriculum: Out-of-class experiences associated with student learning and personal development. Journal of Higher Education, 66, 123-155.

Liepold, M. J., Rasmussen, C. M., Boyce, K., \& Trudeau Poskas, D. (2013). Outside the comfort zone: Strategies for developing emotionally intelligent leaders. Journal of Leadership Education, 12(2), 74-87.

Mattanah, J. F., Ayers, J. F., Brand, B. L., \& Brooks, L. J. (2010). A social support intervention to ease the college transition: Exploring main effects and moderators. Journal of College Student Development, 51(1), 93-108.

Mattanah, J. F., Brooks, L. J., Brand, B. L., Quimby, J. L., \& Ayers, J. F. (2012). A social support intervention and academic achievement in college: Does perceived loneliness mediate the relationship? Journal of College Counseling, 15(1), 93-108.

Musu-Gillette, L., Robinson, J., McFarland, J., KewelRamani, A., Zhang, A., \& Wilkonson Flicker, S. (2016). Status and trends in the education of racial and ethnic groups 2016. Washington, DC: U.S. Department of Education.

Nagelkerke, N. J. D. (1991). A note on a general definition of the coefficient of determination. Biometrika, 78, 691-692. 
Pascarella, E. T., \& Terenzini, P. T. (1977). Patterns of student-faculty informal interaction beyond the classroom and voluntary freshman attrition. Journal of Higher Education, 48(4), 540-552.

Pascarella, E. T., \& Terenzini, P. T. (2005). How college affects students: Vol. 2. A third decade of research. San Francisco, CA: Jossey-Bass.

Pizzolato, J. E., \& Ozaki, C. C. (2007). Moving toward self-authorship: Investigating outcomes of learning partnerships. Journal of College Student Development, 48(2), 196-214.

Prussia, G. E., \& Weis, W. L. (2004). Experiential learning effects on retention: Results from a required MBA course. Journal of College Student Retention: Research, Theory, and Practice, 5(4), 397-407.

Rosenbaum, P. R., \& Rubin, D. B. (1985). Constructing a control group using multivariate matched sampling methods that incorporate the propensity score. American Statistician, 39(1), 33-38.

Scriven, M., \& Paul, R. (1996). Defining critical thinking: A draft statement for the National Council for Excellence in Critical Thinking. Retrieved from http://www.criticalthinking.org/pages/defining-critical-thinking/766

Soria, K. M., Nobbe, J., \& Fink, A. (2013). Examining the intersections between undergraduates' engagement in community service and development of socially responsible leadership. Journal of Leadership Education, 12(1), 117-140.

Soria, K. M., Roberts, J., \& Reinhard, A. (2015). Undergraduate students' strengths awareness and leadership development. Journal of Student Affairs Research and Practice, 52(1), 89103.

Soria, K. M., \& Stubblefield, R. (2014). First-year college students' strengths awareness: Building a foundation for student engagement and academic excellence. Journal of the First-Year Experience and Students in Transition, 26(2), 69-88.

Soria, K. M., \& Stubblefield, R. (2015a). Knowing me, knowing you: Building strengths awareness and belonging in higher education. Journal of College Student Retention: Research, Theory, and Practice, 17(3), 351-372.

Soria, K. M., \& Stubblefield, R. (2015b). Building a strengths-based campus to support student retention. Journal of College Student Development, 56(6), 626-631.

Soria, K. M., \& Taylor, Jr., L. (2016). Strengths-based approaches in college and university student housing: Implications for first-year students' retention and engagement. Journal of College and University Student Housing, 42(2), 60-75. 
Strayhorn, T. L. (2012). College students' sense of belonging: A key to educational success for all students. New York, NY: Routledge.

Sutton, H. (2016). Building a truly inclusive campus starts with student identity. Enrollment Management Report, 20(2), 1-5.

The Program on Intergroup Relations at the University of Michigan. (2007).

The White House Office of the Press Secretary. (2009). President's remarks in Warren, Michigan today and a fact sheet on the American Graduation Initiative. Retrieved from https://www.whitehouse.gov/the-press-office/excerpts-presidents-remarks-warrenmichigan-and-fact-sheet-american-graduation-init

Thoemmes, F. J. (2012). Propensity score matching in SPSS. Retrieved from http://arxiv.org/ftp/arxiv/papers/1201/1201.6385.pdf

Thompson, M. D. (2006). Student leadership process development: An assessment of contributing college resources. Journal of College Student Development, 47(3), 343-350.

Tinto, V. (1993). Leaving college: Rethinking the causes and cures of student attrition (2nd ed.). Chicago, IL: University of Chicago Press.

Tinto, V..(2012). Completing college: Rethinking institutional action. Chicago, IL: University of Chicago Press.

Wagner, W. (2013). The social change model of leadership: A brief overview. Concepts \& Connections: A Publication for Leadership Educators, 15(1), 8-10.

Werner, L. R. (2014). The critical intersections of mindfulness and case-in-point teaching in the undergraduate leadership classroom. Concepts and Connections, 2l(1). National Clearinghouse for Leadership Programs.

Werner, L. R. \& Hellstrom, D. (2016). Engaging young leaders: A modern approach to teaching leadership. Manuscript submitted for publication.

Werner, L., Hellstrom, D., Chung, J., Kessenich, K., Taylor, Jr. L., \& Capeder, A. (2016). Bridging theory and practice in the leadership classroom: Intentional emergence as a modern pedagogy. Journal of Leadership Education, 15(4), 206-216.

Wimmer, G., Meyers, C., Porter, H., \& Shaw, M. (2012). Learning vicariously: Students' reflections of the leadership lessons portrayed in The Office. Journal of Leadership Education, 11(2), 52-71.

Zimmerman-Oster, K., \& Burkhardt, J. C. (1999). Leadership in the making: A comprehensive examination of the impact of leadership development programs on students. The Journal of Leadership Studies, 6(3/4), 50-66. 


\section{Author Biographies}

Dr. Krista M. Soria works as an analyst with the Office of Institutional Research at the University of Minnesota, Twin Cities. Dr. Soria is interested in researching programmatic efforts to enhance college students' leadership development, civic responsibility, and engagement in social change. She can be reached at ksoria@umn.edu.

Dr. Linnette Werner, Director of the Undergraduate Leadership Minor, University of Minnesota, has worked to grow the minor to over 1,800 enrollments per year, begin a research agenda on evidence-based leadership pedagogy, and is the co-creator of the Intentional Emergence Model for teaching leadership. She can be reached at wern0065@umn.edu. 